\title{
DEVELOPMENTAL INDIVIDUAL-DIFFERENCES RELATIONSHIP- BASED (DIR) FLOORTIME DALAM MENINGKATKAN KOMUNIKASI DUA ARAH PADA KASUS AUTISM SPECTRUM DISORDER (ASD)
}

\author{
Stella Rosalina Phandinata ${ }^{1)}$, Ediastri Toto Atmodiwirjo ${ }^{2)}$, Debora Basaria ${ }^{3)}$ \\ Program Studi Magister Psikologi Universitas Tarumanagara \\ 1'stella.rosalina@gmail.com, ${ }^{2}$ ediasri@gmail.com, ${ }^{3}$ deborabasariayulianti@gmail.com
}

\begin{abstract}
Autism Spectrum Disorder (ASD) is a developmental disorder that has communication disorders as its characteristic. Greenspan introduced the DIR Floortime model which is proven to be able to improve the communication circles of ASD child and teens. This study aims to see the role of DIR Floortime in improving two-way communication of adolescent with ASD. With single-subject experimental design, this study consisted of 10 pre-intervention sessions, 20 intervention sessions and 10 post-intervention sessions, 2 sessions in 1 day with 20 minutes duration. Two-way communication capability is measured using Functional Assessment Scale and number of communication circles during the session. Based on an assessment of JW, a 14-year-old teenager with Autism Spectrum Disorder, it is found: JW has a dominant sensory-seeking in the tactile and auditory areas. JW mental age is equal to 6 year-old child. JW has reached the third development milestone, two-way purposeful communication, but JW is not optimal yet in this milestone. From the results, the DIR Floortime is able to improve two-way purposeful communication significantly in adolescent with Autism Spectrum Disorder. In addition, DIR Floortime is also able to increase circles of communication significantly in adolescent with Autism Spectrum Disorder. Specifically, there is an increase in the quantity and also improvement in the quality of opening the communication circles. While the ability to close the communication circles is only improved in quality. JW is able to respond the researcher with series of behavior after the DIR Floortime intervention is given.
\end{abstract}

Keywords: DIT Floortime, two-way communication, circle of communication, autism spectrum disorder, adolescent

\begin{abstract}
ABSTRAK
Autism Spectrum Disorder (ASD) merupakan gangguan perkembangan yang memiliki ciri khas gangguan komunikasi. Greenspan dan Wieder memperkenalkan model DIR Floortime yang mampu meningkatkan lingkaran komunikasi pada anak dan remaja dengan gangguan Pervasive Developmental Disorder. Penelitian ini bertujuan untuk melihat peran DIR Floortime dalam meningkatkan komunikasi dua arah pada kasus remaja dengan ASD. Desain penelitian menggunakan single-subject experimental design. Penelitian ini terdiri dari 10 sesi pre-intervention, 20 sesi intervensi dan 10 sesi post-intervention dengan intensitas 2 sesi dalam 1 hari dengan durasi 20 menit. Kemampuan komunikasi dua arah diukur dengan menggunakan Functional Emotional Assessment Scale dan jumlah lingkaran komunikasi selama sesi berlangsung. Berdasarkan hasil asesmen pada JW, seorang remaja dengan Autism Spectrum Disorder berusia 14 tahun, diketahui bahwa: JW memiliki sensory-seeking yang dominan pada area taktil dan auditori. Usia mental JW setara dengan 6 tahun. JW sudah mencapai tonggak perkembangan ketiga, yakni komunikasi dua arah, namun belum optimal. Dari hasil intervensi diketahui bahwa DIR Floortime terbukti mampu meningkatkan komunikasi dua arah yang bertujuan secara signifikan pada remaja dengan Autism Spectrum Disorder. Selain itu, DIR Floortime juga mampu meningkatkan lingkaran komunikasi secara signifikan pada remaja dengan Autism Spectrum Disorder. Secara spesifik, terjadi peningkatan pada kuantitas dan kualitas JW dalam membuka lingkaran komunikasi atau mampu untuk lebih banyak memulai interaksi dengan peneliti. Sedangkan kemampuan menutup lingkaran komunikasi hanya meningkat secara kualitas pada JW setelah intervensi DIR Floortime diberikan. JW lebih mampu untuk merespon peneliti dengan rentetan perilaku.
\end{abstract}

Kata Kunci: DIR Floortime, komunikasi dua arah, lingkaran komunikasi, autism spectrum disorder, remaja. 


\section{PENDAHULUAN}

Autism Spectrum Disorder (ASD) merupakan gangguan perkembangan yang memiliki ciri khas gangguan komunikasi maupun perilaku perilaku repetitif atau minat yang terbatas (American Psychiatric Association, 2013). Secara spesifik, gangguan komunikasi pada ASD ini muncul dalam bentuk kegagalan dalam komunikasi non-verbal, merespon hubungan sosioemosional dan kegagalan dalam membangun, mempertahankan serta memahami hubungan (American Psychiatric Association, 2013). Untuk menangani masalah perilaku pada individu ASD, banyak terapi yang tersedia, yakni modifikasi perilaku dengan penggunaan reinforcement dan prinsip extinction, terapi sensori integrasi, diet gluten-free maupun pengobatan medis sudah digunakan untuk mengurangi masalah perilaku pada gangguan ASD (Mash \& Barkley, 2014; Schaaf, Hunt, \& Benevides, 2012; Aman \& Langworthy, 2000) Kebanyakan intervensi yang dijalankan oleh anak dengan gangguan ASD lebih banyak berfokus pada gangguan perilaku, yakni perilaku repetitif, stereotip, hiperaktif dan inattention. Padahal gangguan ASD ini tidak hanya memiliki ciri khas adanya perilaku repetitif dan stereotip, namun juga memiliki gangguan pada aspek komunikasi sosial.

Intervensi yang paling banyak dilakukan sejauh ini untuk menangani masalah komunikasi sosial pada anak ASD adalah Applied Behavior Analysis-Verbal Behavior (ABA-VB). ABA-VB banyak dilakukan untuk meningkatkan kemampuan komunikasi anak pada anak ASD, yakni anak belajar untuk mengungkapkan apa yang diinginkannya kepada orang di sekitarnya, memberikan label kepada stimulus non-verbal (gambar, benda dan sebagainya), mengimitasi secara verbal lawan bicaranya dan memberikan respon berdasarkan stimulus verbal dari lawan bicaranya (Lim \& Draper, 2011). Namun beberapa tahun terakhir telah membawa pertanyaan tambahan tentang kefektivitasan model ABA. Dalam masalah tertentu telah dilaporkan kemampuan seorang anak untuk menggeneralisasi, ketergantungan pada isyarat, kurangnya spontanitas dan inisiatif, penggunaan hafalan untuk menanggapi, dan kegagalan untuk menggeneralisasi perilaku untuk memberikan respon yang tepat karena sulit menggeralisasi keterampilan dipelajari dalam percobaan di lingkungan buatan, dibandingkan lingkungan yang natural (Matson et al; Schreibman; dalam Pajareya, K \& Nopmaneejumruslers, 2011; Salomon, Necheles, Ferch, \& Bruckman, 2007). Padahal anak harus berinteraksi dan berkomunikasi secara logis, disengaja, dan kreatif dalam lingkungan yang lebih natural (Greenspan et al., 2001; Greenspan \& Wieder, 1998).

Greenspan dan Wieder (1998) menemukan pendekatan sosial pragmatis yang dapat mengembangkan kemampuan komunikasi tersebut yang lebih spontan, panjang dan spesifik. Pendekatan sosial pragmatis adalah pendekatan yang berfokus pada spontanitas dan inisiasi dari luar untuk mengikuti fokus atensi dari anak dan motivasi anak. Pendekatan ini menggunakan aktivitas sehari-hari dan interaksi-interaksi di sekitar anak untuk mendukung perkembangan sosial komunikasi anak (Prizant \& Wetherby, 1998). Greenspan memperkenalkan model DIR Floortime dengan tiga prinsip, yakni Developmental, Individual-Difference, Relationship-Based (Greenspan \& Wieder, 2006). Pada prinsip pertama, Developmental, Greenspan dan Wieder (2006) berpendapat bahwa anak memiliki tonggak fungsi perkembangan emosional yang berbeda-beda untuk mengintegrasikan seluruh kapasitas (sosial, motorik, kognitif, bahasa, spasial dan sensori) untuk mencapai sebuah tujuan yang berarti secara emosional. Menurut Greenspan dan Wieder (2006), fungsi emosional tersebut terdiri dari enam tonggak perkembangan yakni: (1) attention and self regulation, (2) intimacy, engagement and relating, (3) two-way purposeful communication, (4) complex communication and social problem solving, (5) emotional ideas (create and use ideas) dan (6) emotional thinking (building bridges between two or more ideas) (Greenspan \& Wieder, 2006). Selanjutnya, pada prinsip kedua DIR Floortime, yakni Individual 
Differences in Sensory Modulation, Sensory Processing and Motor Planning, Greenspan dan Wieder (2006) memahami bahwa adanya perbedaan sensori dan perencanaan motorik berbeda untuk setiap anak. Pada prinsip DIR Floortime yang ketiga, yakni Relationship and Interaction, Greenspan menjelaskan bagaimana faktor lingkungan dan fungsi individual yang unik membentuk pengalaman interaksi anak.

DIR Floortime merupakan metode yang dapat digunakan oleh orangtua dan guru dalam membangun kemampuan sosial, secara spesifik keterampilan interpersonal dan emosional pada anak maupun remaja dengan gangguan perkembangan (Greenspan $\&$ Wieder, 2006). Dalam DIR Floortime ini, anak didorong untuk berinteraksi secara non verbal dan atau verbal (Greenspan \& Wierder, 2006). Intervensi DIR Floortime dirancang sesuai dengan kemampuan dan kebutuhan anak, remaja maupun orang dewasa, yakni sejauh mana penguasaan pada tonggak perkembangan emosional yang ada (Greenspan \& Wieder, 2008). Dionne dan Martini (2011) menemukan bahwa pendekatan floortime ini mampu meningkatkan lingkaran komunikasi anak ASD. Selain itu, penelitian yang ada juga menemukan bahwa pendekatan DIR Floortime mampu untuk mengoptimalkan perkembangan fungsi emosional pada anak ASD (Pajareya, K \& Nopmaneejumruslers, K., 2011). Tidak hanya itu, Wieder dan Greenspan (2005) mempublikasikan penelitian yakni setelah $10-15$ tahun anak diberikan terapi DIR Floortime menjadi remaja yang lebih optimal pada perkembangan fungsi emosionalnya, yakni lebih empati, kreatif dan reflektif secara signifikan pada komunikasi sosial serta memiliki hubungan dengan teman sebaya yang lebih baik.

Di Indonesia, DIR Floortime terbukti mampu untuk meningkatkan kecakapan sosial pada anak dengan gangguan ASD, secara spesifik mampu untuk meningkatkan kemampuan bahasa pada anak dengan gangguan ASD (Pangestika, 2013). DIR Floortime juga terbukti mampu untuk meningkatkan kecakapan sosial pada anak dengan gangguan ASD, secara spesifik mampu untuk meningkatkan empati dan kerja sama pada anak (Sukinah, 2008) Berdasarkan penjelasan di atas, dapat dilihat bahwa penelitian-penelitian yang ada, DIR Floortime mampu untuk mengoptimalkan perkembangan emosional anak, dalam hal ini secara spesifik adalah tonggak perkembangan emosional ketiga, yaitu meningkatkan komunikasi dua arah. Oleh karena itu, pada studi ini, peneliti ingin melihat peran DIR Floortime dapat meningkatkan komunikasi dua arah pada kasus remaja ASD yang dilihat dari meningkatnya jumlah lingkaran komunikasi yang bertujuan pada kasus remaja ASD.

Rumusan masalah dalam penelitian ini adalah apakah intervensi DIR Floortime dapat meningkatkan komunikasi dua arah pada kasus remaja dengan Autism Spectrum Disorder?

Tujuan dari penelitian ini adalah untuk mengetahui peran DIR Floortime dalam meningkatkan komunikasi dua arah pada kasus satu remaja dengan Autism Spectrum Disorder. Hasil penelitian ini diharapkan dapat digunakan untuk mengatasi masalah keterampilan sosial pada remaja dengan Autism Spectrum Disorder khususnya pada meningkatnya komunikasi dua arah dengan intervensi DIR Floortime.

\section{Autism Spectrum Disorder}

Pada aspek kognitif, 93\% remaja dan orang dewasa dengan ASD menunjukkan adanya peningkatan di area bahasa dan kemampuan komunikasi namun masih kesulitan dalam bahasa ekspresif. Namun kebanyakan mayoritas dari yang mengalami peningkatan di atas tidak memiliki gangguan intelektual. Sedangkan pada remaja ASD yang memiliki gangguan intelektual, lebih dari $50 \%$ tidak mengalami peningkatan dalam kemampuan verbal (Ratto \& Mesibov, 2015).Pada aspek psikososial, remaja dengan gangguan perkembangan pervasif (ASD) menunjukkan gangguan perilaku maupun emosi (Lecavalier, 2006). Secara spesifik gangguan perilaku dan emosi ini berupa gejala kecemasan, depresi dan perilaku hyperactive-inattention. Di samping itu beberapa penelitian menemukan bahwa 
pada remaja dengan ASD, terlihat adanya kemajuan pada kemampuan komunikasi, secara spesifik kemampuan dalam merespon dan percakapan (Ratto \& Mesibov, 2015). Namun kualitas dari hubungan persahabatan akan tetap terganggu.

\section{DIR Floortime}

DIR Floortime adalah sebuah terapi sistematis yang dilakukan dengan cara melibatkan kerjasama antara anak dan orangtua untuk mendukung tonggak perkembangan sosial anak yakni kemampuan interaksi dan komunikasi (Greenspan \& Wieder, 2006). Perbedaan dengan permainan biasa adalah orangtua atau terapis memegang peran dalam perkembangan anak. Dalam permainan tersebut, anak didorong untuk berinteraksi secara non verbal dan atau verbal (Greenspan \& Wieder, 2006). Berbeda dengan terapi bermain lainnya, DIR Floortime tidak terpaku pada struktur dalam aktivitas bermain. Terapis mengobservasi permainan apa yang dimainkan oleh anak, bergabung dengan aktivitas anak, mengikuti cara bermain dan aktivitas yang dilakukan oleh anak, kemudian berusaha memperpanjang permainan dengan anak berdasarkan strategi di tonggak perkembangan yang ada (Greenspan \& Wieder, 2006).

$$
\text { Pada prinsip Developmental, }
$$

Greenspan berpendapat bahwa anak memiliki level fungsi perkembangan emosional yang berbeda-beda untuk mengintegrasikan seluruh kapasitas (sosial, motorik, kognitif, bahasa, spasial dan sensori) untuk mencapai sebuah tujuan yang berarti secara emosional. Menurut Greenspan, fungsi emosional tersebut terdiri dari enam kapasitas anak. Kapasitas pertama adalah attention and self regulation. Pada kapasitas ini, anak mampu untuk memberikan atensi dan minat kepada lingkungan di sekitarnya. Pada kapasitas kedua adalah intimacy, engagement and falling in love, di mana anak mampu untuk mulai menggunakan gestur dan suara untuk berinteraksi dengan lingkungan sekitarnya. Tonggak ketiga yang harus dicapai adalah two-way purposeful communication. Komunikasi ini dapat berupa gestur maupun verbal. Pada tonggak ini, setiap kali anak dituntut untuk mampu menutup atau membuka minimal 10 siklus komunikasi (Greenspan \& Wieder, 2006). Pada tonggak two-way purposeful communication anak belajar untuk membuka dan menutup siklus komunikasi dengan berbagai gestur sekaligus untuk menunjukkan apa yang diinginkannya.

Pada tonggak yang keempat, yakni complex communication and social problem solving, anak belajar untuk berkomunikasi dengan bahasa tubuh yang kompleks untuk memecahkan masalah secara sosial (minimal 50 siklus komunikasi). Pada kapasitas kelima, create and use ideas, anak mampu untuk memberikan makna kepada simbol atau kata untuk mengekspresikan apa dirasakannya melalui permainan simbolik. Anak mulai mengenal emosi yang dirasakan dengan mengeksperimenkan berbagai situasi dalam permainan. Pada tonggak yang keenam, building bridges between two or more ideas, anak mulai menghubungan emosi yang dirasakan dengan penjelasan secara logis (Greenspan \& Wieder, 2006).

Pada prinsip kedua DIR Floortime, yakni Individual Differences in Sensory Modulation, Sensory Processing and Motor Planning, Greenspan memahami bahwa adanya perbedaan sensori dan perencanaan motorik berbeda untuk setiap anak. Modulasi sensori termasuk adanya under atau overreactivity pada suara, sentuhan, penglihatan, penciuman, rasa dan pergerakkan. Proses sensori meliputi kemampuan anak untuk memproses informasi auditori, bahasa dan visual spasial. Proses ini terdiri dari kemampuan untuk menerima, melakukan koding dan memahami urutan pola yang abstrak. Prinsip Relationship and Interaction menjelaskan bagaimana faktor lingkungan dan fungsi individual yang unik membentuk pengalaman interaksi anak. Interaksi yang tepat mampu untuk mengembangkan intensi dan emosi pada anak. Pada prinsip relationship dan interaction, pola interaksi afektif yang tepat dapat dilakukan untuk mendukung perkembangan anak. 


\section{METODE PENELITIAN}

Partisipan dalam penelitian ini adalah seorang remaja dengan kondisi sebagai berikut: (1) usia 14 tahun, (2) mengalami gangguan Autism Spectrum Disorder, (3) laki-laki (4) status sosial menengah ke atas.; (5) didiagnosis di usia 4 tahun (6) secara keseluruhan masalah perilaku tidak tergolong dalam masalah klinis (7) tidak sedang mengikuti terapi, (8) sudah memiliki kemampuan pada tonggak perkembangan intimacy, engagement and relating. Kemampuan ini meliputi kemampuan untuk menanggapi tawaran dari lingkungannya dan menunjukkan rasa gembira serta rasa ingin tahunya. Tonggak perkembangan ini menjadi kriteria dikarenakan untuk masuk ke tonggak kemampuan komunikasi dua arah, anak sudah harus mampu untuk melewati tonggak komunikasi intimacy, engagement and relating.

Peneliti menggunakan jenis penelitian applied research yakni clinical case study. Menurut Shaughnessy, Zechmeister, \& Zechmeister et al., (2012), desain penelitian ini merupakan deskripsi dan analisis dari satu individu. Pada umumnya penelitian ini digunakan untuk program intervensi atau implementasi di mana diperlukan eksternal validitas yang lebih tinggi yaitu sejauh mana intervensi tersebut efektif di lapangan (Shaughnessy, Zechmeister, \& Zechmeister, 2012)

\section{Desain Penelitian}

Penelitian ini menggunakan single-case experimental design (ABA) dalam mengukur efektivitas intervensi. Menurut Barlow dan Hersen (1984), pada desain ini peneliti mengobservasi perubahan pada fase baseline, yakni observasi perilaku sebelum intervensi diberikan, fase intervensi, yakni observasi perilaku selama intervensi diberikan dan fase baseline yang kedua yakni observasi perilaku saat intervensi ditarik kembali (Barlow \& Hersen, 1984). Selanjutnya dalam penelitian ini, fase baseline pertama akan disebut sebagai sesi pre-intervention dan fase baseline kedua akan disebut sebagai sesi post-intervention.

\section{Pengukuran}

Instrumen pengukuran yang digunakan adalah (1) lembar observasi untuk mengukur jumlah lingkaran komunikasi. Perilaku anak yang termasuk ke dalam memulai interaksi atau membuka lingkaran komunikasi dapat berupa kontak mata, non-verbal (gestur, gerak isyarat) atau verbal, seperti menarik tangan peneliti, menunjukkan ekspresi terlebih dahulu kepada peneliti, atau membuat suara yang ditujukan untuk peneliti. Sedangkan perilaku yang termasuk dalam menutup lingkaran komunikasi antara lain kontak mata dengan peneliti sebagai respon, memeluk balik ketika dipeluk, menunjukkan ekspresi tertentu sebagai respon dari perilaku peneliti, menunjuk atau mengeluarkan suara sebagai respon ketika ditanya atau diminta.

Observasi ini dilakukan oleh tim peneliti dan satu mahasiswa Magister Profesi Psikologi Klinis Anak dengan melihat rekaman interaksi antara anak dan peneliti selama 20 menit di setiap sesi, dimulai dari sesi pre-intervention, intervensi dan post-intervention. Di samping itu, (2) kuesioner Functional Emotional Assessment Scale (FEAS) oleh Greenspan, Gangi dan Wieder (2001) juga digunakan untuk penelitian ini pada setting bermain. Dalam penelitan ini FEAS pada tonggak perkembangan ketiga yang terdiri dari kemampuan untuk membuka lingkaran komunikasi, memberikan sinyal, menutup lingkaran komunikasi, tidak menunjukkan kemarahan atau agresi serta kemampuan untuk menggunakan bahasa digunakan. FEAS memiliki validitas yang baik untuk membedakan antara anak dengan perkembangan yang tipikal dan anak dengan regulatory disorders dan pervasive developmental disorders (Greenspan, Gangi, $\&$ Wieder, 2001). Reliabilitas FEAS tinggi dalam mengobservasi secara langsung maupun dengan rekaman video (Greenspan, Gangi, \& Wieder, 2001).

\section{Prosedur Penelitian}

Pada penelitian ini, prosedur yang dilakukan adalah sebagai berikut: Pertama, peneliti melakukan screening dan asesmen 
terhadap partisipan penelitian dengan melakukan screening menggunakan Childhood Autism Rating Scale (CARS) untuk memahami tingkat gejala autisme, Child Behavior Checklist (CBCL) untuk melihat gambaran masalah perilaku pada anak. Kedua, peneliti melakukan asesmen berdasarkan DIR model dengan menggunakan asesmen profil sensori dan motorik, observasi tonggak perkembangan emosional 1-6 di kehidupan sehari-hari serta Standford Binet. Setelah selesai melakukan asesmen, peneliti membuat rancangan intervensi DIR Floortime yang sesuai dengan profil sensori dan minat serta tonggak perkembangan anak saat ini.

Dalam menjalankan terapi, tim peneliti pada awalnya melakukan 10 sesi preintervention (sebelum intervensi diberikan), lalu 20 sesi intervensi dan diikuti dengan 10 sesi post-intervention (intervensi ditarik kembali). Pada 40 sesi intervensi ini, pengukuran checklist jumlah lingkaran komunikasi dan form observasi Functional Emotional Assessment Scale (Greenspan dan Wieder, 2006) pada tonggak perkembangan ketiga yakni two-way purposeful communication. Dalam satu hari, peneliti menjalankan 2 sesi yakni masing-masing sesi berdurasi 20 menit. Peralatan yang digunakan dalam penelitian ini adalah permainan sensori auditori atau taktil, tikar, kamera, sd card dan tripod. Pada sesi ganjil, peneliti menggunakan permainan sensori auditori, antara lain bebek mainan, kerincingan, toples berisi senter, garpusendok, dan sebagainya. Pada sesi genap, peneliti menggunakan permainan sensori taktil, antara lain sikat halus, sarung tangan bulu, pasir kinestetik, waterbeads dan sebagainya.

\section{HASIL DAN PEMBAHASAN}

\section{Hasil Screening}

Skor dari hasil screening JW menunjukkan bahwa JW termasuk dalam kategori mild autism spectrum disorder. Secara keseluruhan masalah perilaku JW tidak termasuk ke dalam area klinis. Oleh karena itu, proses asesmen terhadap JW dilanjutkan.
Tabel 1.

Data Diri Subyek (JW)

\begin{tabular}{cc}
\hline Jenis Kelamin & Laki-laki \\
Tanggal lahir & Jakarta, 11 November 2002 \\
Usia & 14 tahun 4 bulan \\
Agama & Kristen \\
Pendidikan & Kelas 5 SD di SD Inklusi \\
Didiagnosa & PDD-NOS di usia 4 tahun \\
Urutan Bersaudara & Anak kedua dari dua bersaudara \\
\hline
\end{tabular}

\section{Hasil Asesmen}

Pada aspek fisik, JW memiliki sensory-seeking dominan pada sensoryseeking auditori dan taktil. Permainan sensori auditori dan taktil untuk membantu JW mengungkapkan apa yang diinginkannya pada saat bermain secara lebih spesifik dan panjang. Selain itu, pada motor-planning, JW terkadang membutuhkan waktu yang lebih lama untuk melakukan kegiatan motorik tertentu. Hal ini membuat peneliti memberikan waktu kepada JW untuk merespon maupun memulai inisiatif ketika bermain. Pada aspek kognitif, usia mental JW setara dengan 6 tahun. Oleh karena itu, dalam berinteraksi peneliti lebih mengandalkan benda-benda konkret yang ada di hadapan JW. Pada aspek psikososial, JW sudah menguasai tonggak perkembangan pertama (attention and selfregulation) dan kedua (intimacy, engagement and relating) namun belum optimal di tonggak perkembangan ketiga (two-way purposeful communication). Pada tonggak pertama, JW mampu untuk berbagi atensi dengan melihat ke arah benda yang ditunjuk oleh lawan bicaranya. Pada tonggak perkembangan kedua, yakni intimacy, engagement and relating, JW sudah mampu untuk menunjukkan rasa ingin tahu, kontak mata serta menanggapi respon peneliti. Namun pada tonggak perkembangan ketiga, JW hanya mampu melakukan 3-4 lingkaran komunikasi dari kriteria minimal 10 lingkaran komunikasi.

Program intervensi dalam penelitian ini dilakukan dengan struktur (1) pembukaan, (2) sesi sensory play (auditori dan taktil) dan (3) penutup, baik pada sesi pre-intervention, intervensi maupun postintervention. Sebelum sesi intervensi diberikan, 10 sesi pre-intervention dilakukan untuk mendapatkan data baseline pada kemampuan komunikasi anak. Selama 20 
sesi intervensi, strategi DIR Floortime dan pengukuran kemampuan komunikasi juga dilakukan. Setelah 20 sesi intervensi diberikan, 10 sesi post-intervention dilakukan, yakni intervensi ditarik kembali dan pengukuan tetap dilakukan. Setiap sesi berdurasi 20 menit, dengan fekuensi 2 sesi dalam 1 hari dan 5 hari dalam seminggu.

\section{Pelaksanaan Intervensi.}

Pada sesi pre-intervention, JW masih cukup pasif dan cenderung hanya menutup lingkaran komunikasi serta mengikuti arahan peneliti dalam bermain. Secara lebih mendalam, JW juga masih lebih banyak merespon peneliti dengan gestur tunggal dan belum dengan rentetan perilaku. Pada sesi pre-intervention, peneliti cenderung mengarahkan JW topik permainan dan belum memberikan kesempatan kepada JW untuk mulai membuka lingkaran komunikasi. Pada sesi intervensi, peneliti mulai menerapkan strategi DIR Floortime. Dengan strategi invite circles, total communication, sportcaster, wait dan communication tempation, peneliti memancing inisiatif JW untuk membuka lingkaran komunikasi yang bertujuan. Sedangkan strategi playfully persist dan easy choices dilakukan untuk memfasilitasi JW dalam menutup lingkaran komunikasi. Selain strategi-strategi pada tonggak perkembangan two-way purposeful communication, peneliti juga menerapkan beberapa strategi di tonggak perkembangan pertama dan keuda yakni support regulation dan notice and adjust, serta gaze tracking. Strategi-strategi ini hanya dilakukan pada saat JW merasa cemas. Pada sesi postintervention, meskipun peneliti tidak mengikuti alur permainan JW, JW berusaha untuk membuka lingkaran komunikasi dengan tujuan mengarahkan peneliti ke jenis permainan yang diinginkan oleh JW.

\section{Evaluasi Pelaksanaan Program Intervensi.}

Peran DIR Floortime dilihat berdasarkan Kemampuan Komunikasi Dua Arah pada FEAS dan jumlah lingkaran komunikasi dengan analisa two-standard deviation band. Peneliti melihat sejauh mana terjadi peningkatan pada sesi intervensi dan post-intervention dibandingkan sesi preintervention.

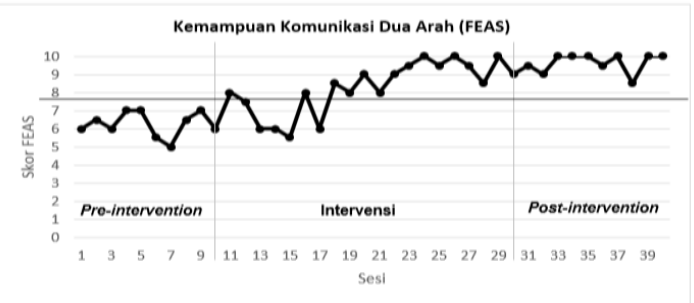
sesi pre-intervention

Gambar 1. Grafik Kemampuan Komunikasi Dua Arah

\section{Kemampuan Komunikasi Dua Arah}

Berdasarkan grafik 1, dapat dilihat bahwa mulai dari sesi intervensi kedelapan (sesi 18) sampai sesi post-intervention terakhir (sesi 40), skor tonggak perkembangan komunikasi dua arah yang bertujuan pada Functional Emotional Assessment Scale berada dua standard deviasi di atas skor pada sesi pre-intervention. Dengan demikian dapat dikatakan bahwa ada peningkatan yang terjadi secara signifikan pada kemampuan komunikasi dua arah yang bertujuan pada JW di sesi intervensi dan post-intervention jika dibandingkan dengan kemampuan JW di sesi pre-intervention.

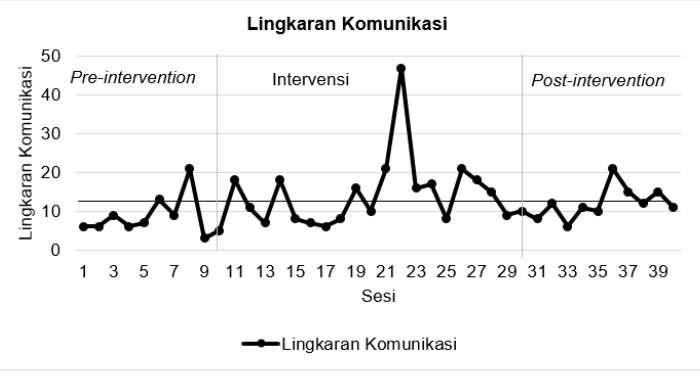

$\overline{\text { pre-intervention }}$ Garis

Gambar 2. Grafik Lingkaran Komunikasi

\section{Lingkaran Komunikasi.}

Berdasarkan grafik di atas dapat dilihat bahwa jumlah lingkaran komunikasi pada sesi intervensi ke-11 (sesi 21), 12 (sesi 22), 16 (sesi 26) dan sesi post-intervention ke-6 (sesi 36), 7 (sesi 37), dan 9 (sesi 39) secara signifikan berada jauh di atas jumlah lingkaran komunikasi pada sesi preintervention. Lebih dari dua sesi postintervention memiliki lingkaran komunikasi di atas dua standard-deviation band dari sesi 
pre-intervention. Dengan kata lain secara umum, ada peningkatan yang signifikan pada total lingkaran komunikasi.

Tabel 2.

Jumlah Lingkaran Komunikasi Terbuka dan Tertutup

\begin{tabular}{lccc}
\hline & $\begin{array}{c}\text { Jumlah Lingkaran Komunikasi } \\
\text { Pre- } \\
\text { intervention }\end{array}$ & Intervensi & $\begin{array}{c}\text { Post- } \\
\text { Intervention }\end{array}$ \\
\hline $\begin{array}{l}\text { Total Lingkaran } \\
\begin{array}{l}\text { Komunikasi } \\
\text { Lingkaran }\end{array}\end{array}$ & 8 & 15 & 12 \\
$\begin{array}{l}\text { Komunikasi } \\
\text { Terbuka }\end{array}$ & 2 & 8 & 5 \\
$\begin{array}{l}\text { Lingkaran } \\
\text { Komunikasi } \\
\text { Tertutup }\end{array}$ & 8 & 12 & \\
\hline
\end{tabular}

Tabel 3.

Gestur Komunikasi pada Lingkaran Komunikasi yang Dibuka

\begin{tabular}{lccc}
\hline \multicolumn{3}{c}{ Gestur Terbanyak dalam Membuka Lingkaran: } \\
\hline & $\begin{array}{c}\text { Pre- } \\
\text { intervention }\end{array}$ & Intervensi & $\begin{array}{c}\text { Post- } \\
\text { Intervention }\end{array}$ \\
$\begin{array}{l}\text { Menyebutkan } \\
\text { kata (v) }\end{array}$ & 25 & 100 & 61 \\
$\begin{array}{l}\text { Kontak mata } \\
\text { (nv) }\end{array}$ & 24 & 220 & 123 \\
$\begin{array}{l}\text { Mengambil } \\
\text { benda (nv) }\end{array}$ & 21 & 76 & 51 \\
$\begin{array}{l}\text { Mengeluarkan } \\
\text { suara tidak } \\
\text { berarti (v) }\end{array}$ & 16 & 55 & 61 \\
$\begin{array}{l}\text { Menunjukkan } \\
\text { ekspresi (nv) }\end{array}$ & 12 & 154 & 52 \\
\hline
\end{tabular}

Keterangan: (v) gestur verbal;(nv) gestur non-verbal

Tabel 4.

Gestur Komunikasi pada Lingkaran Komunikasi yang Ditutup

\begin{tabular}{|c|c|c|c|}
\hline \multicolumn{4}{|c|}{ Gestur Terbanyak dalam Menutup Lingkaran: } \\
\hline & $\begin{array}{c}\text { Pre- } \\
\text { intervention }\end{array}$ & Intervensi & $\begin{array}{c}\text { Post- } \\
\text { Intervention }\end{array}$ \\
\hline $\begin{array}{l}\text { Menyebutkan kata } \\
\text { (v) }\end{array}$ & 79 & 169 & 215 \\
\hline Kontak mata (nv) & 70 & 150 & 220 \\
\hline $\begin{array}{l}\text { Menunjukkan } \\
\text { ekspresi (nv) }\end{array}$ & 39 & 166 & 85 \\
\hline $\begin{array}{l}\text { Mengeluarkan } \\
\text { suara tak berarti } \\
\text { (v) }\end{array}$ & 35 & 47 & 47 \\
\hline $\begin{array}{l}\text { Melihat apa yang } \\
\text { dilakukan } \mathrm{P}(\mathrm{nv})\end{array}$ & 32 & 71 & 53 \\
\hline
\end{tabular}

Keterangan: (v) gestur verbal;(nv) gestur non-verbal

Secara spesifik dibandingkan sesi preintervention, terjadi peningkatan pada jumlah lingkaran komunikasi yang dibuka, namun jumlah lingkaran yang ditutup masih sama pada sesi post-intervention. Meskipun begitu, secara kualitas jumlah lingkaran komunikasi yang ditutup meningkat. Dalam menutup lingkaran komunikasi, JW yang tadinya merespon dengan gestur tunggal, sekarang mampu melakukan dua gestur verbal-non verbal sekaligus (seperti: tersenyum sambil menyebutkan kata). Begitu juga dengan gestur dalam membuka lingkaran komunikasi, JW yang tadinya cenderung membuka lingkaran komunikasi hanya dengan gestur tunggal (kontak mata atau menyebutkan kata), menjadi mampu melakukan beberapa gestur sekaligus dalam memulai interaksi dengan peneliti (kontak mata, menyebutkan kata sambil mengambil benda).

Monitoring dan evaluasi dilakukan untuk mengetahui perilaku JW pada interaksi sehari-hari setelah intervensi $D I R$ Floortime diberikan. Peneliti menemukan bahwa JW lebih aktif membuka lingkaran komunikasi dengan ayah JW. Sebelum intervensi, JW cenderung membuka lingkaran komunikasi dengan ayahnya lebih banyak dengan memanggil "daddy". Namun, ketika ayah JW tidak merespon panggilan JW, JW akan kembali diam. Sedangkan setelah intervensi diberikan, JW lebih memanggil ayahnya berkali-kali secara terus-menerus, berdiri di hadapan ayahnya dan melakukan kontak mata dengan ayahnya sambil menyentuh tangan ayahnya berkalikali saat ayahnya tidak merespon. Selain itu, dengan pengasuh, setelah sesi postintervention, JW yang tadinya mengatakan "makan" karena mengimitasi apa yang dikatakan pengasuh, sekarang sudah mampu mengatakan "makan" sebagai gestur untuk membuka lingkaran komunikasi dengan pengasuh. JW berusaha memberitahu pengasuh bahwa ia makan dan minum dengan baik dan cepat. Dari sini dapat disimpulkan bahwa DIR Floortime mampu meningkatkan kemampuan komunikasi dua arah pada remaja dalam interaksinya seharihari.

Peningkatan kemampuan komunikasi dua arah yang bertujuan peneliti lebih banyak memberikan kesempatan kepada JW untuk membuka lingkaran komunikasi dengan strategi wait. Menurut Davis, Isaacson dan Harwell (2014), anak dengan kemampuan yang lambat dalam memproses sensori auditori, kognitif dan motorik membutuhkan waktu yang lebih lama dalam memproses apa yang sedang terjadi dengan 
lingkungannya sehingga anak cenderung lebih lambat dalam merespon atau mencetuskan inisiatif yang baru. Pada penelitian ini, peneliti mulai mengurangi inisiatif dalam membuka lingkaran komunikasi dengan menunggu dan merespon setiap gestur JW sehingga JW berusaha membuat gestur yang baru.

Selain itu, selama sesi intervensi, JW lebih mampu untuk membuka dan menutup lingkaran komunikasi lebih banyak pada permainan stimulasi taktil, seperti bermain sarung tangan bulu, meminta untuk diusap dan sebagainya ataupun auditori, seperi ketuk benda. Hal ini sesuai dengan profil sensori JW yang dominan pada sensoryseeking pada auditori dan taktil. Menurut Greenspan dan Wieder (2006), seorang anak akan lebih mudah berkomunikasi melalui kebutuhan profil sensorinya. Sedangkan pada peningkatan secara kualitas, strategi playfully persist berperan. Menurut Davis, Isaacson dan Harwell (2014), strategi playfully persist dapat digunakan untuk membuat anak dan remaja belajar untuk melengkapi lingkaran komunikasi secara lebih persisten dan lebih jelas. Di sisi lain hal ini peningkatan kualitas pada kemampuan menutup lingkaran komunikasi ini membuat kuantitas menutup lingkaran komunikasi tetap sama karena apa yang diinginkan oleh JW sudah dikemukakan dengan rentetan perilaku dalam satu lingkaran komunikasi tanpa perlu ditanya lebih lanjut.

Di samping itu, pada beberapa sesi intervensi dan post-intervention, terjadi penurunan skor, di mana pada sesi ini JW masuk ke dalam ruangan sudah dalam keadaan cemas. Padahal untuk mencapai target tonggak perkembangan komunikasi dua arah yang bertujuan, anak perlu mencapai tonggak perkembangan attention and self-regulation terlebih dahulu (Greenspan \& Wieder, 2006). Hal ini membuat waktu yang ada lebih banyak dihabiskan peneliti untuk mendukung tonggak perkembangan pertama terlebih dahulu sekitar 5-10 menit di awal sesi sebelum masuk ke tonggak ketiga. Hal ini membuat komunikasi dua arah yang bertujuan pada JW menjadi kurang maksimal pada sesi-sesi di atas.

\section{SIMPULAN DAN SARAN}

\section{Simpulan}

Hasil intervensi pada studi kasus ini menunjukkan bahwa DIR Floortime terbukti mampu meningkatkan komunikasi dua arah yang bertujuan secara signifikan pada remaja dengan Autism Spectrum Disorder. DIR Floortime mampu meningkatkan kemampuan untuk membuka lingkaran komunikasi, kemampuan JW dalam memberikan sinyal permainan secara terarah dan kemampuan JW dalam menutup lingkaran komunikasi dengan rentetan perilaku. Secara spesifik DIR Floortime mampu meningkatkan kemampuan untuk membuka lingkaran komunikasi secara signifikan pada studi kasus ini baik secara kuantitas maupun kualitas. Pada kemampuan menutup lingkaran komunikasi, DIR Floortime belum mampu meningkatkan kemampuan ini secara signifikan. Meskipun begitu secara kualitatif, terdapat peningkatan dalam kemampuan menutup lingkaran komunikasi. JW sudah mulai mampu untuk merespon peneliti dengan rentetan perilaku atau gestur yang bertujuan, tidak hanya merespon sederhana dengan gestur tunggal.

\section{Saran bagi Penelitian Selanjutnya}

Pada penelitian selanjutnya dapat dilakukan intervensi DIR Floortime pada remaja Autism Spectrum Disorder dengan profil individual differences yang sama dengan JW pada studi kasus ini. Selain itu, dalam melakukan DIR Floortime sebaiknya orangtua/ pengasuh sebagai terapis dengan melakukan tahapan

Dalam melakukan pengukuran Functional Emotional Assessment Scale terhadap tonggak perkembangan anak dalam sesi pre-intervention, sesi intervensi dan sesi post-intervention sebaiknya peneliti melakukan pengukuran terhadap tonggak-tonggak perkembangan yang berada di bawah tonggak perkembangan yang ingin dicapai. Dalam penelitian selanjunya, orangtua atau pengasuh disarankan membuat jurnal untuk melihat bagaimana keseharian anak dan apa saja yang terjadi dengan anak dari sesi awal sampai akhir untuk melihat sejauh mana hal-hal di luar intervensi mempengaruhi kemampuan anak. 


\section{Saran bagi Pihak Berkepentingan}

Orangtua JW sebaiknya meluangkan waktu dengan JW. Orangtua yang lebih mengandalkan terapis, pengasuh dan guru seharusnya diberikan pemahaman mengenai pentingnya hubungan dan emosi positif yang terjalin antara orangtua dan anak terhadap kemampuan emosional anak. Selanjutnya, orangtua JW sebaiknya memahami dan belajar untuk memenuhi kebutuhan sensori JW. Pada profil JW, JW memiliki kebutuhan sensori auditori serta taktil yang cukup tinggi. Mengacuhkan keinginan JW untuk disentuh dan berteriak perlu dihindari oleh orangtua JW. Sebaliknya dibanding mengacuhkan permintaan stimulasi sensori dari JW, orangtua maupun pengasuh sebaiknya memanfaatkan permintaan tersebut untuk mengembangkan komunikasi dua arah yang bertujuan dari JW dan menggunakan nada yang lebih rendah untuk berkomunikasi dengan JW

Orangtua juga diharapkan dapat menjalankan terapi DIR Floortime. Waktu yang maksimal yang dapat digunakan adalah pagi hari. Orangtua JW disarankan dapat mengikuti sesi pelatihan secara langsung oleh psikolog yang sudah memiliki lisensi dalam memberikan pelatihan kepada orangtua di bidang $D I R$ Floortime. Selain itu, instruksi direktif terhadap JW dapat dikurangi dan menggunakan strategi $D I R$ dalam berkomunikasi dengan JW. Dengan tidak langsung memberikan apa yang diinginkan JW, tetapi bertanya terlebih dulu agar JW belajar mengkomunikasikan apa yang diinginkannya dengan lebih baik.

\section{DAFTAR PUSTAKA}

Aman, M. G., \& Langworthy, K. S. (2000). Pharmacotherapy for hyperactivity in children with autism and other pervasive developmental disorders. Journal of Autism and Developmental Disorders, Vol. 30, No. 5.

American Psychiatric Association. (2013). Diagnostic and statistical manual of mental disorders (5th ed). Washington, DC: Author.

Barlow, D. H., \& Hersen, M. (1984). Single Case Experimental Designs: Strategies of Studying Behavioral Change (2th ed). New York: Pergamon Press.

Buie, T. (2013). The relationship of autism and gluten. Clinical Therapeutics, Volume 35, Number 5.
Davis, A., Isaacson, L., \& Harwell, M. (2014). Floortime strategies to promote development in children and teens. Michigan: Paul H. Brookes Publishing.

Davis, N., \& Kollins, S. (2012). Treatment for co-occurring attention deficit/hyperactivity.

Neurotherapeutics, (2012) 9:518-530.

Dionne, M., \& Martini, R. (2011). Floor time play with a child with autism: A single-subject study. Canadian Journal of Occupational Therapy, 78, 196-203.

Greenspan, S. I., \& Wieder, S. (2006). Engaging autism. Philadelphia: A Merloyd Lawrence Book.

Greenspan, S. I., \& Wieder, S. (2006). Infant and early childhood mental health: A comprehensive developmental approach to assessment and intervention. Washington, DC: American Psychiatric Publishing, Inc.

Greenspan, S. I., Gangi, G. D., \& Wieder, S. (2001). Assessment scale (FEAS) for infancy and early childhood: Clinical and research applications. Bethesda, MD: Interdisciplinary Council on Developmental and Learning Disorders.

Greenspan, S., \& Wieder, S. (2006). The child with special needs: Anak berkebutuhan khusus. Jakarta: Yayasan Ayo Main!

Lecavalier, L. (2006). Behavioral and emotional problems in young people with pervasive developmental disorders: Relative prevalence, effects of subject characteristics, and empirical classification. J Autism Dev Disord, 36:1101-1114.

Lim, H., \& Draper, E. (2011). The effects of music therapy incorporated with applied behavior analysis verbal behavior approach for children with autism spectrum disorders. Journal of Music Therapy, 532-550.

Mash, E. J., \& Barkley, R. (2014). Child psychopathology (3rd ed). New York: Guillford Press.

Pajareya, K \& Nopmaneejumruslers, K. (2011). A pilot randomized controlled trial of DIR/Floortime ${ }^{\mathrm{TM}}$ parent 
training intervention for pre-school children with autistic spectrum disorders. Autism, June 2011, p. 1-16.

Pangestika, V. (2013). Pengaruh Pendekatan Floortime terhadap Kemampuan Berbahasa pada Anak Autistik. Malang: Fakultas Pendidikan Psikologi Universitas Negeri Malang.

Prizant, B. M., \& Wetherby, A. M. (1998). Understanding the continuum of discrete trial traditional behavioral to social-pragmatic developmental approaches in communication enhancement for young children with autism/PDD. Seminars in Speech and Language, 19, p. 329-352.

Ratto, A. B., \& Mesibov, G. B. (2015). Autism spectrum disorders in adolescence and adulthood: Longterm outcomes and relevant issues for treatment and research. Life Sciences China, Vol.58, no.10: 1010-1015.

Salomon, R., Necheles, J., Ferch, C., \& Bruckman, D. (2007). Pilot study of a parent training program for young children with autism. Autism, vol 11(3), 205-224.

Schaaf, R., Hunt, J., \& Benevides, T. (2012). Occupational therapy using sensory integration to improve participation of a child with autism: A case report. The American Journal of Occupational Therapy, 547-555.

Shaughnessy, J. J., Zechmeister, E. B., \& Zechmeister, J. S. (2012). Research methods in psychology (9th ed). New York: Mc-Graw Hill.

Sukinah. (2008). Metode Floortime dalam Terapi Bermain dapat Mengembangkan Kecakapan Sosial Anak Autis.

Wieder, S., \& Greenspan, S. (2005). Can children with autism master the core deficits and become empathetic, creative, and reflective? The Journal of Developmental and Learning Disorders, vol. 9, p. 1-29. 